\title{
The Impact of Liberalization on Determinants of Bank Efficiency: Evidence from Malaysian Commercial Banks
}

\author{
YUE MA ${ }^{1}$, WEI NI SOH ${ }^{2 *}$ \\ ${ }^{1}$ School of Business and Economics, UNIVERSITI PUTRA MALAYSIA, MALAYSIA. Email: mayue01@foxmail.com \\ ${ }^{2}$ Department of Accounting and Finance, UNIVERSITI PUTRA MALAYSIA, MALAYSIA. \\ Email: sohweini@upm.edu.my
}

\begin{abstract}
This paper aims to examine the impact of liberalization in 2009 on the determinants of bank efficiency in Malaysia by employing a two-stage approach within the context of the growing number of foreign commercial banks. Commercial banks can play a vital role in the internationalization and diversification of Malaysia's financial sector. In the initial stage, measuring the efficiency score of 19 commercial banks throughout 2008 to 2019 by using the Data Envelopment Analysis (DEA). Multivariate panel regressions were then used to determine the impact of liberalization on the determinants of bank efficiency in 2009. As a result, domestic commercial banks seem to be more competitive than their foreign counterparts. The findings signify that bank size, market power, capitalization, and liquidity all have a positive impact on technical efficiency. However, credit risk, bank diversification, and inflation all have a negative impact. The control of the effects of liberalization, bank size, capitalization, bank's market power, and liquidity remain positive. However, bank diversification and inflation flip negative to positive, whereas credit risk becomes less explanatory. The findings will provide bank stakeholders, regulators, investors, and regulators with important insights into the impact of liberalization measures on bank efficiency and its determinants.
\end{abstract}

Keywords: Liberalization; Commercial Banks; Technical Efficiency; Malaysia; Data Envelopment Analysis; Multivariate Panel Regression.

JEL Classification: C33, E44, G21

Received: July 08, 2021

Accepted: September 23, 2021 


\title{
El Impacto de la Liberalización en los Determinantes de la Eficiencia Bancaria: Datos de los Bancos Comerciales de Malasia
}

\author{
YUE MA ${ }^{1}$, WEI NI SOH ${ }^{2 *}$ \\ ${ }^{1}$ School of Business and Economics, UNIVERSITI PUTRA MALAYSIA, MALAYSIA. Email: mayue01@foxmail.com \\ ${ }^{2}$ Department of Accounting and Finance, UNIVERSITI PUTRA MALAYSIA, MALAYSIA. \\ Email: sohweini@upm.edu.my
}

\begin{abstract}
RESUMEN
Este trabajo pretende examinar el impacto de la liberalización en 2009 sobre los determinantes de la eficiencia bancaria en Malasia, empleando un enfoque de dos etapas en el contexto del creciente número de bancos comerciales extranjeros. Los bancos comerciales pueden desempeñar un papel vital en la internacionalización y diversificación del sector financiero de Malasia. En la etapa inicial, se midió la puntuación de eficiencia de 19 bancos comerciales a lo largo de 2008 a 2019 utilizando el Análisis Envolvente de Datos (DEA). A continuación, se utilizaron regresiones de panel multivariadas para determinar el impacto de la liberalización en los determinantes de la eficiencia bancaria en 2009. Como resultado, los bancos comerciales nacionales parecen ser más competitivos que sus homólogos extranjeros. Los resultados indican que el tamaño del banco, el poder de mercado, la capitalización y la liquidez tienen un impacto positivo en la eficiencia técnica. Sin embargo, el riesgo de crédito, la diversificación bancaria y la inflación tienen un impacto negativo. El control de los efectos de la liberalización, el tamaño del banco, la capitalización, el poder de mercado del banco y la liquidez siguen siendo positivos. Sin embargo, la diversificación bancaria y la inflación pasan de ser negativas a positivas, mientras que el riesgo de crédito se vuelve menos explicativo. Las conclusiones proporcionarán a las partes interesadas en los bancos, a los reguladores, a los inversores y a los responsables de la reglamentación, importantes conocimientos sobre el impacto de las medidas de liberalización en la eficiencia de los bancos y sus determinantes.
\end{abstract}

Palabras clave: Liberalización; Bancos comerciales; Eficiencia técnica; Malasia; Análisis envolvente de datos; Regresión de panel multivariante.

Clasificación JEL: C33, E44, G21 


\section{Introduction}

The 1997 Asian financial crisis had a major impact on Malaysia's financial sector, it exposed the country's fractured banking system. At the same time, the World Trade Organization is pressuring countries to expand their financial markets to increase access to foreign banks (BNM, 1999a). Given the growing challenges and progressively competitive environment, the restructuring and rationalization of the domestic banking sector are inevitable in the context of economic globalization (BNM,1999b). As of 1999, there have been 71 banking establishments (ref tab.1) with 2,712 branches throughout the country. Malaysia appears to have a disproportionately large number of banking institutions, leading to some resources being wasted because of duplication of branches in the same region (BNM, 1999a). Thus, the domestic banking sector was consolidated into ten banking groups by Bank Negara Malaysia in 1999, resulting in a more stable and competitive banking system with no adjustment in the number of foreign banks. In 2006, the merger process continued with the acquisition of Southern Bank by the anchor bank CIMB.

In April 2009, new liberalization measures were implemented with the aim of strengthening Malaysia's economic relations with other countries and strengthening the key position of the financial sector in economic development. In 2009, liberalization measures granted five commercial banking licenses with a paid-up capital of RM300 million, and locally registered foreign banks are allowed to open up to four new branches (BNM, 2009). These five commercial banks are the National Bank of Sumitomo Mitsui Banking Corporation (Japan), Abu Dhabi (United Arab Emirates), Mizuho Corporate Bank (Japan), PT Bank Mandiri (Indonesia), and BNP Paribas SA (France). In 2011, Hong Leong Bank acquired EON Bank as a part of the voluntary merger. At the end of 2019, there were 8 domestic commercial banks and 18 foreign commercial banks in Malaysia.

Table 1 The Number of Commercial Banks in Malaysia 1999-2019

\begin{tabular}{lccc}
\hline \multicolumn{1}{c}{ Commercial Banks } & 1999 & 2009 & 2019 \\
\hline${ }^{*}$ Domestic Commercial Banks & 21 & 9 & 8 \\
${ }^{*}$ Foreign Commercial Banks & 13 & 13 & 18 \\
Finance Companies $^{\mathrm{a}}$ & 25 & - & - \\
Merchant Banks $^{\mathrm{b}}$ & 12 & 15 & 11 \\
Total & 71 & 37 & 37 \\
\hline
\end{tabular}

a. All previous finance companies have been acquired by respective anchors (commercial banks).

b. All merchant banks have been converted or merged into investment banks.

Source: Bank Negara Malaysia (1999, 2019)

If more foreign capital is drawn into the market, it could bring more capital into the banking sector, while new foreign banks entering the market will compete alongside local banks. As more foreign banks are allowed to enter the Malaysian banking sector, it is bound to increase Malaysia's linkages with other economies. Ang and McKibbin (2007) examined financial liberalization as a beneficial effect in stimulating the development of the financial sector by eliminating the repressing policies. The entry of foreign banks will bring more capital, advanced management experience, and technology, which in turn will enhance market competition and promote the development of the Malaysian banking sector, adding a boost to economic development. Bank Negara Malaysia released the Financial Sector Blueprint (FSB) 2011-2020 in 2011 with the intention of making the financial sector more competitive, dynamic, inclusive, diversified, and integrated in order to create an efficient and world-class financial service provider (BNM, 2011). As a result, the government, financial sector authorities, and academic researchers have paid close attention to the success of Malaysian commercial banks.

Technical efficiency is an important indicator of a bank's performance, it reflects the bank's ability to which the number of inputs can be reduced while a certain amount of output is being produced or a certain number of inputs is being used to optimize the outputs. Technical efficiency, which consists of pure technical efficiency and scale efficiency, provides additional information on sources of efficiency. 
Purely technical efficiency, which generally refers to the capabilities of bank managers to get the most out of the bank's resources, with higher pure technical efficiency indicating greater capability. The utilization of scale economies by working at the point where the output frontier produces constant returns to scale is referred to as scale efficiency (Tan \& Anchor, 2017). Furthermore, various factors influence bank performance, including internal factors such as bank size, credit risk, capital risk, liquidity risk, and so on, as well as external macroeconomic factors including economic conditions, inflation, and economic policy. Several studies have examined bank efficiency and its determinants in different years using different methods (Abel, 2018; Azad, Munisamy, Masum, Saona, \& Wanke, 2017; Kamarudin, Sufian, \& Nassir, 2016b), but few studies have examined whether liberalization measures have increased the number of foreign commercial banks and influenced the determinants of bank efficiency (Saha, Ahmad, and Dash, 2015). Therefore, the purpose of this study is to assess whether liberalization measures have affected the determinants of bank efficiency.

In the following three aspects, this paper complements the current literature and extends previous research. First, the current research investigates changes in bank efficiency before and after the implementation of liberalization measures. It should be noted that the research period corresponds to the FSB, which can evaluate the effectiveness of the measures. Second, it examines the determinants of technical efficiency for commercial banks in Malaysia. Third, the liberalization's impact on the determinants of bank efficiency is also estimated.

According to the findings, domestic commercial banks are more effective than foreign commercial banks. Moreover, the results illustrate that bank size, capitalization, liquidity, and market power all have a significant beneficial impact on bank efficiency, while credit risk, bank diversification, and inflation have a significant negative impact. Eventually, bank diversification and inflation turn positive after the effect of liberalization is controlled, but credit risk loses its explanatory power.

The structure of the article is as follows. The second part is the literature review on determinants of bank efficiency. The data and methodology for estimating the efficiency score and its determinants using DEA and multivariate panel regression are presented in the third section. Part four examines bank efficiency and its determinants for commercial banking. Ended by conclusion and suggestions.

\section{Literature Review}

The main objective of this paper is to determine the impact of liberalization on the determinants of bank efficiency in Malaysia. The first section reviews the theory of market competition on bank efficiency. The second section reviews the literature related to the determinants of bank efficiency.

\subsection{Quiet Life Hypothesis}

The "Quiet Life Hypothesis" composed by Hicks (1935) provides the fundamental definition of the nexus between competition and market performance. Instead of extracting rents in a monopoly market, the company uses market forces to allow inefficient allocation of resources rather than maximizing profits. The reason for this is that the subjective cost of management to achieve the best profit may far exceed the margin income. This hypothesis indicates that in a concentrated market there is less competitive pressure, which leads to a reduction in the management staff's efforts for effective operations. Therefore, the increasing number of commercial banks will strengthen market competition and further affect bank efficiency. Liberalization measures aim at increasing the market competition in the Malaysian banking industry by increasing the number of foreign commercial banks, which is consistent in line with Financial Sector Blueprint (FSB) 2011-2020 in 2011 (BNM, 2011). In other words, greater competition will lead to greater efficiency as a result of the corporation is attempting to survive in the fierce competition by optimizing the determinants of banking efficiency.

\subsection{The Determinants of Bank Efficiency}

The research of bank efficiency became popular in Malaysia after the banking industry was consolidated in 1999. Njie (2007) examines the changes in the efficiency of commercial banks after the 
financial liberalization in Malaysia in 1999 using the DEA-Malmquist index. The findings encapsulate that government intervention is one of the driving factors of efficiency in the Malaysian banking sector. Rahim (2017) applied 21 commercial banks, including foreign banks and commercial banks in Malaysia, and compared their cost-effectiveness by using the DEA model between 2006 to 2014. The empirical results exemplify that the efficiency of foreign banks is lower than domestic partners. Sufian, Kamarudin, and Nassir (2016) employed a Bootstrap-DEA method to compute the variable rate of return on the technical efficiency scale for commercial banks from 1999 to 2008 in Malaysia and performed a bootstrap regression to identify origins impact on bank efficiency. According to the results, domestic commercial banks have a higher mean efficiency than their foreign peers, which is consistent with Ng, Wong, Yap, and Khezrimotlagh (2014); The results also indicate that the bank size, non-interest income, and capitalization are positively impacted technical efficiency, as well as the banking sector's concentration and risk. Conversely, market capitalization harms technical efficiency.

In earlier, Ong, Lim, and Teh (2011) calculate the foreign and domestic commercial bank's pure technical efficiency and their determinants by using the DEA method and Tobit model from 2002 to 2009. The research portrays that from 2002 to 2009, domestic Malaysian banks are more technically efficient than foreign banks on a purely technical basis. Bank efficiency has a positive association with profitability and liquidity. However, the quality of loans, capital strength, and asset size harm pure technical efficiency. By using the same methods as Ong et al., (2011), From 2005 to 2012, Saha et al., (2015) examined the technical efficiency of commercial banks in Malaysia and their determinants, finding that domestic banks have greater efficiency than foreign banks. The results demonstrate that the size, deposit advances, and return on assets all hurt bank efficiency, while personnel expenses to total assets and non-performing assets to net loans and advances are having a positive effect.

Studies on bank efficiency have also been investigated in other countries. Pancurova and Lyocsa (2013) measured the cost efficiency of commercial banks of 11 Central and Eastern European Countries (CEEC) throughout the 2005-2008 period. The findings illustrate that foreign banks have a higher cost efficiency than domestic banks in CEEC countries and that there is a positive relationship between size and capitalization and CE. While the loans-to-assets ratio has defaced CE. Nevertheless, Partovi and Matousek (2019) applied a modified DEA model analysis of the technical efficiency and allocation efficiency and its determinants for Turkish banks from 2002 to 2017. The result signifies that domestic banks are more efficient than foreign banks in Turkey. The result also shows the NPLs had a negative impact on technical efficiency. Concerning the Chinese banking industry, Tuo (2016) has examined the efficiency of Chinese banks using a slacks-based measure (SBM) from 2003 to 2014 and decomposed its affecting factors. The results indicate the technical efficiency experienced an increasing trend until 2014 after the reform of the Chinese banking industry but in contradiction with Hou, Wang, and Zhang (2014) that the technical efficiency of Chinese commercial banks declined from 2006 to 2010 . The results indicate the return on assets, non-interest income, and lending rate positively impacted bank efficiency. Conversely, the cost-to-income ratio, Herfindahl-Hirschman index, average total assets, loanto-deposit ratio, and monetary growth are negative linked to bank efficiency.

There is a big gap in the literature on the Malaysian commercial banking industry. Many researchers focus on studying a sector of Islamic banking or the difference between Islamic and conventional banking (Kamarudin \& Yahya, 2013; Loong; Kamarudin, Sufian, \& Naseem, 2017; Haque, Tausif, \& Ali, 2020). Few studies have measured the impact of liberalization measures on the determinants of commercial banks (Saha et al., 2015). The banking industry in Malaysia experienced tremendous change in the past twenty years. It is necessary to evaluate the performance of liberalization measures announced in 2009. This study fills a gap in the existing literature by comparing and contrasting the productivity of domestic and foreign commercial banks. It is also worth noting that the effects of liberalization policies on bank efficiency determinants have been investigated. Overall, this study will measure the bank efficiency of domestic and foreign commercial banks, and the determinants of technical efficiency in Malaysia from 2008 to 2019. 


\section{Data and Methodology}

The data of this research covers 19 commercial banks (including 8 domestic commercial banks and 11 foreign commercial banks) for the period 2008-2019 in Malaysia. All of these internal bank data sources are: (1) Bankscope database created by Bureau Van Dijk; and (2) annual financial statements. The World Bank database is used to obtain the macroeconomic variables. All currencies are converted to Malaysian Million Ringgit (RM) for comparison. Table 2 shows the sample of studies in this paper.

Table 2 List of Research Samples

\begin{tabular}{llll}
\hline No. & Domestic Commercial Banks & No. & Foreign Commercial Banks \\
\hline 1 & Malayan Banking Berhad & 1 & HSBC Bank Malaysia Berhad \\
\hline 2 & CIMB Bank Berhad & 2 & OCBC Bank (Malaysia) Berhad \\
\hline 3 & Public Bank Berhad & 3 & Bank of China (Malaysia) Berhad \\
\hline 4 & RHB Bank Berhad & 4 & Bangkok Bank Berhad \\
\hline 5 & AmBank (M) Berhad & 5 & Citibank Berhad \\
\hline 6 & Alliance Bank Malaysia Berhad & 6 & JP Morgan Chase Bank Berhad \\
\hline 7 & Affin Bank Berhad & 7 & MUFG Bank (Malaysia) Berhad \\
\hline 8 & Hong Leong Bank Berhad & 8 & Deutsche Bank (Malaysia) Berhad \\
\hline & & 9 & Standard Chartered Bank Malaysia Berhad \\
\hline & 10 & United Overseas Bank (Malaysia) Berhad \\
\hline \multirow{2}{*}{ Source: Bank Negara Malaysia } & 11 & Bank of Nova Scotia Berhad
\end{tabular}

\subsection{Data Envelopment Analysis}

DEA is a modern 'data-driven' method for evaluating the performance of a group of peer entities called decision-making units (DMUs) that transform multiple inputs into multiple outputs (Cooper, 2011). It was first proposed by Charnes, Cooper and Rhodes (1978) and studied as an effective technique for evaluating relative efficiency. Technical efficiency is a measure of relative efficiency that includes numerous outputs and inputs. While the effective production capacity frontier refers to optimizing the selection of inputs and outputs, the DEA method can be input-oriented or outputoriented. The input-oriented model where minimizes the number of inputs and kept the outputs at current levels. In contrast, the output-oriented model maximizes the outputs and keeps the inputs at their current levels (Banker, Charnes, \& Cooper, 1984). In this research, we believe that to measure a certain number of outputs while minimizing the inputs, the input-oriented method is adopted.

The DEA method used in the current research is based on the variable return to scale (VRS) by adding additional requirements in the constant return to scale (CRS): $\sum \lambda=1$ (Coelli, Prasada-Rao, \& Battese, 1998).

$$
\begin{gathered}
\min _{\theta, \lambda} \theta \\
\text { Subject to: } \sum_{j=1}^{N} Y \lambda \geq y_{i} ; \theta x_{i} \geq \sum_{j=1}^{N} X \lambda \quad i=1,2, \ldots, N \\
\sum \lambda=1 ; \lambda \geq 0 \quad j=1,2, \ldots, N
\end{gathered}
$$

Where:

$\theta \quad$ is technical efficiency;

$\mathrm{N} \quad$ is the number of DMUs;

$\mathrm{X} \quad$ is the $K \times N$ input matrix;

$\mathrm{Y} \quad$ is the $M \times N$ output matrix;

$x_{i} \quad$ is the $K \times 1$ input vector of the $i^{\text {th }}$ DMUs;

$y_{i} \quad$ is the $M \times 1$ output vector of the $i^{\text {th }}$ DMUs;

$\lambda \quad$ is an intensity $N \times 1$ vector of constant. 


\subsection{Inputs and Outputs Selection in DEA}

Cooper, Seiford, and Tone (2002) argued that select inputs and outputs must comply with the requirement:

$$
n \geq \max \{m * s, 3(m+s)\}
$$

Where:

$\mathrm{n} \quad$ is the number of DMUs;

$\mathrm{m} \quad$ is the number of inputs;

$s \quad$ is the number of outputs.

There are three main approaches to the selection of inputs and outputs, namely the production approach, intermediation approach, and the value-added approach. The intermediation approach is commonly used since we measure the efficiency of the commercial banking industry rather than a bank. Furthermore, the intermediation approach is more appropriate to estimate the efficiency of the banking industry in developing countries (Bader, Mohamad, Arrif, \& Hassan, 2008). According to Sufian and Kamarudin (2015); Loong et al., (2017); and Kasim, Ramli, Baten, Jamil, and Taleb (2019), this research uses the intermediation approach because we believe that the bank acts as an intermediary to facilitate funding between borrowers and lenders. Therefore, three inputs and two outputs are applied. The three inputs are X1: deposits, X2: labour, and X3: capital, while Y1: loans and Y2: investments as outputs. Table 3 shows the descriptive statistics used to create the efficiency frontier.

Table 3 Descriptive Statistics of Inputs and Outputs in the DEA Model (RM mil)

\begin{tabular}{|c|c|c|c|c|c|c|c|c|}
\hline & \multicolumn{2}{|l|}{ Mean } & \multicolumn{2}{|l|}{ Max } & \multicolumn{2}{|l|}{ Min } & \multicolumn{2}{|l|}{ SD } \\
\hline & $\mathrm{DCB}$ & FCB & $\mathrm{DCB}$ & FCB & DCB & FCB & $\mathrm{DCB}$ & FCB \\
\hline \multicolumn{9}{|c|}{ Inputs } \\
\hline $\mathrm{X} 1$ & 1756.9 & 257.1 & 6625.0 & 822.4 & 239.6 & 2.7 & 1597.8 & 242.3 \\
\hline$\times 2$ & 6287.2 & 1119.7 & 18256.6 & 4450.2 & 878.8 & 19.8 & 4748.3 & 1159.0 \\
\hline X3 & 175482.7 & 29607.2 & 602066.9 & 103598.6 & 26560.0 & 421.4 & 146647.6 & 28425.5 \\
\hline \multicolumn{9}{|c|}{ Outputs } \\
\hline Y1 & 8473.5 & 1292.7 & 51250.9 & 5125.5 & 1100.2 & 22.5 & 8363.7 & 1292.0 \\
\hline Y2 & 143337.7 & 21994.7 & 513419.7 & 84718.4 & 16545.0 & 65.9 & 130629.6 & 23189.1 \\
\hline
\end{tabular}

As mentioned above, the input-oriented DEA model is used to measure the efficiency of commercial banks. After these three efficiency scores have been collected, we performed parametric (t-test) and non-parametric (Mann-Whitney and Kruskall-Wallis) tests to examine whether bank efficiency scores are significant between domestic and foreign commercial banks as well as to check the robustness.

\subsection{Multivariate Panel Regression}

The multivariate panel regression has been employed to empirically assess the effect of determinants on technical efficiency at the second stage. Before performing the regression, the Tau-b correlation test was performed in the case of correlation problems. Bank efficiency and the impact of determinants measured by the two-stage method, which combines the DEA method and the multivariate regression method ((Banker \& Natarajan, 2005; Banker, Chang, \& Lee, 2010; Kamarudin, Sufian, \& Nassir, 2016a; Kamarudin, et al., 2016b; Loong et al., 2017). Since the panel data estimation takes into account changes in both cross-sectional and time series variations, it offers the benefit of using all available information that cannot be detected in the cross-sectional and time series data alone (Cosar, 2012). Consequently, by providing a large number of data points and integrating the features of the cross-sectional and time series data, the panel data increases the efficiency of econometric estimation. Therefore, many researchers used multivariate panel regression to measure the impact and significance of determinants. In this study, we will use 11 multivariate panel regression models to 
determine the impact of liberalization measures on bank-specific and macroeconomic variables. The use of dummy variables should follow two principles: First, none of the original categorical variables should be used. Second, we can always use a dummy variable with one less category than any categorical variable number of categories (Asteriou \& Hall, 2007).

By using the technical efficiency score as the dependent variable, we extend the regression model as follow:

$$
\begin{aligned}
& L N(T E)_{j t}=\alpha_{t}+\beta_{j t}\left(L N T A_{j t}+L N N P L s_{j t}+L N E T A_{j t}+L N N I I G R_{j t}+L N B D T D_{j t}\right. \\
& +L N L O A N S T A_{j t}+L N G D P_{j t}+L N I N F L_{j t}+F L P_{j t}+L N T A_{j t} * F L P_{j t}+L N N P L s_{j t} \\
& * F L P_{j t}+L N E T A_{j t} * F L P_{j t}+L N N I I G R_{j t} * F L P_{j t}+L N B D T D_{j t} * F L P_{j t} \\
& \left.+L N L O A N S T A_{j t} * F L P_{j t}+L L N G D P_{j t} * F L P_{j t}+L N I N F L_{j t} * F L P_{j t}\right)+\varepsilon_{j t}
\end{aligned}
$$

Where:

$\begin{array}{ll}L N(T E)_{j t} & \text { is the natural logarithm of the j-th bank's technical efficiency in period t; } \\ \text { LNTA } & \text { is the natural logarithm of total assets; } \\ \text { LNNPLs } & \text { is the natural logarithm of non-performing loans to total loans; } \\ \text { LNETA } & \text { is the natural logarithm of equity over total assets; } \\ \text { LNNIIGR } & \text { is the natural logarithm of non-interest income to gross revenue; } \\ \text { LNBDTD } & \text { is the natural logarithm of the deposits of banks to total deposits; } \\ \text { LNLOANSTA is the natural logarithm of net loans to total assets; } \\ \text { LNGDP } & \text { is the natural logarithm of gross domestic products; } \\ \text { LNINFL } & \text { is the natural logarithm of the inflation rate; } \\ \text { FLP } & \text { is a dummy variable for the policy of financial liberalization; } \\ \alpha & \text { is the intercept; } \\ \beta & \text { is the coefficient vector; } \\ \varepsilon_{j t} & \text { is the random error; } \\ j & \text { is the bank observation } j ; \\ t & \text { is the year } t .\end{array}$

Finally, to get more robust results, a step-wise regression model was applied. Ordinary Least Square (OLS) is commonly be used in empirical studies. Due to the individual effect of variables, the OLS is not always appropriate. Hence, some tests are used to identify the most suitable method. Before using the measurement, the Breusch Pagan Langragian Multiplier (BPLM) test should be conducted in order to identify either OLS or Generalized Least Square (GLS) as suitable. If the test accepts the null hypothesis ( $p$-value $>0.05$ ), the OLS will be applied; otherwise, the GLS is more suitable. The Random Effect Model (REM) and Fixed-Effect Model (FEM) are the two most commonly used techniques (FEM) for GLS. The intercept in the FEM model can differ between individuals because cross-sectional units have their characteristics. Furthermore, the REM assumes that individual unit intercepts are taken randomly from a much larger population, while the mean value remains constant. If the regressors $\beta$ and $X$ of the error component are expected to be uncorrelated, REM may be appropriate if $\beta$ and $X$ are correlated, whereas FEM is more suitable (Kamarudin, Sufian, Nassir, Anwar, \& Hussain, 2019). The Hausman test is used to test whether REM or FEM. If the test accepts the null hypothesis ( $p$-value>0.05), the REM will be employed, otherwise, FEM is applicable.

To deal with the residual problems of heteroskedasticity and autocorrelation that could arise in regression, this study uses a clustering technique to produce an unbiased standard error (Hoechle, 2007). To test for the multicollinearity problem, the study examines the variance inflation factor (VIF) between the explanatory variables. According to Gujarati and Porter (2009), the VIF is a way to test for covariance effects between independent variables in a regression model. Figures for all variables should ensure that they are less than 5 . Descriptive statistics for the regression explanatory variables are given in Table 4. 
Table 4 Descriptive Statistic of Bank specific and Macroeconomic Variables

\begin{tabular}{|c|c|c|c|}
\hline Variables & Mean & SD & Note \\
\hline \multicolumn{4}{|c|}{ Bank Specific } \\
\hline LNTA & 10.83 & 1.455 & $\begin{array}{l}\text { A proxy of bank size computed as the natural logarithm of total } \\
\text { assets }\end{array}$ \\
\hline LNNPLS & 0.24 & 1.528 & $\begin{array}{l}\text { A proxy of credit risk computed as the natural logarithm of non- } \\
\text { performing loans ratio }\end{array}$ \\
\hline LNETA & 2.297 & 0.385 & $\begin{array}{l}\text { A proxy of capitalization computed as the natural logarithm of } \\
\text { equity over total assets }\end{array}$ \\
\hline LNNIIGR & 3.601 & 0.372 & $\begin{array}{l}\text { A proxy of bank diversification computed as the natural logarithm } \\
\text { non-interest income to gross revenue }\end{array}$ \\
\hline LNBDTD & 2.350 & 0.824 & $\begin{array}{l}\text { A proxy of bank market power computed as the natural logarithm } \\
\text { of bank's deposits over total deposits }\end{array}$ \\
\hline LNLOANSTA & 3.939 & 0.633 & $\begin{array}{l}\text { A proxy of liquidity computed as the natural logarithm of total } \\
\text { loans to total assets }\end{array}$ \\
\hline \multicolumn{4}{|c|}{ Macroeconomics } \\
\hline LNGDP & 13.89 & 0.235 & $\begin{array}{l}\text { A proxy of economic condition computed as the natural logarithm } \\
\text { of gross domestic products }\end{array}$ \\
\hline LNINFL & 0.62 & 0.651 & $\begin{array}{l}\text { A proxy of inflation computed as the natural logarithm of the } \\
\text { consumer price growth rate }\end{array}$ \\
\hline FLP & 0.857 & 0.351 & $\begin{array}{l}\text { Dummy variables for the financial liberalization policy announced } \\
\text { in } 2009 \text { that takes value } 1 \text { for the year after } 2009 \text {, otherwise } 0 \text {. }\end{array}$ \\
\hline
\end{tabular}

\section{Results and Discussion}

After calculating the efficiency using the DEA method, the average efficiency scores of domestic and foreign commercial banks were calculated. Table 5 shows the average technical efficiency, pure technical efficiency, and scale efficiency of commercial banks from 2008 to 2019.

\subsection{The efficiency of Domestic and Foreign Commercial Banks}

Table 5 Efficiency Scores for Domestic and Foreign Commercial Banks 2008-2019

\begin{tabular}{llll|lll}
\hline \multirow{2}{*}{ Year } & \multicolumn{3}{l|}{ Domestic Commercial Banks } & \multicolumn{3}{|l}{ Foreign } \\
& TE & PTE & SE & TE & PTE & SE \\
\hline 2008 & 0.805 & 0.908 & 0.885 & 0.761 & 0.831 & 0.913 \\
2009 & 0.892 & 0.957 & 0.930 & 0.816 & 0.913 & 0.901 \\
2010 & 0.993 & 0.994 & 0.999 & 0.957 & 0.975 & 0.982 \\
2011 & 0.918 & 0.999 & 0.919 & 0.842 & 0.942 & 0.897 \\
2012 & 0.917 & 1.000 & 0.918 & 0.873 & 0.952 & 0.918 \\
2013 & 0.877 & 0.991 & 0.885 & 0.886 & 0.955 & 0.924 \\
2014 & 0.916 & 0.995 & 0.920 & 0.908 & 0.962 & 0.942 \\
2015 & 0.745 & 0.985 & 0.756 & 0.816 & 0.915 & 0.889 \\
2016 & 0.977 & 0.987 & 0.990 & 0.924 & 0.938 & 0.984 \\
2017 & 0.982 & 0.988 & 0.994 & 0.964 & 0.973 & 0.991 \\
2018 & 0.904 & 0.969 & 0.934 & 0.900 & 0.963 & 0.935 \\
2019 & 0.896 & 0.972 & 0.922 & 0.906 & 0.953 & 0.948 \\
\hline Mean & 0.902 & 0.979 & 0.921 & 0.882 & 0.942 & 0.936 \\
\hline
\end{tabular}

As the results show, domestic commercial banks dominate in mean technical efficiency $(90.2 \%>88.2 \%)$, and mean pure technical efficiency $(97.9 \%>94.2 \%)$ suggests that the domestic banks can produce more outputs by using the same percentage of inputs. In other words, foreign banks exhibit $11.8 \%$ inefficiency and they are less efficient than their domestic counterparts ( $9.8 \%$ inefficiency) 
due to the problem that the mean pure technical efficiency outweighs mean scale efficiency (Kamarudin, Sufian, Loong, \& Anwar, 2017). The advantage of foreign commercial banks is that the mean scale efficiency $(93.6 \%>92.1 \%)$ is higher than their counterparts. Combining the performance of domestic and foreign commercial banks, the increase in the number of banks following the economic liberalization policy has been followed by an increase in bank efficiency. This suggests that the financial liberalization policy may increase the bank efficiency of banks due to lifting many restrictions and government involvement stimulates banking efficiency (Njie, 2007).

\subsection{Robustness Checks for Bank Efficiency}

Table 6 presents the results of statistical tests for domestic and foreign commercial banks' efficiency scores. According to the parametric T-test and the non-parametric Mann-Whitney and Kruskall-Wallis tests, domestic commercial banks in Malaysia have a higher mean pure technical efficiency $(0.979>$ 0.942 ) than foreign commercial banks, which is statistically significant at the $1 \%$ level. Conversely, foreign commercial banks have examined they have higher mean scale efficiency $(0.936>0.921)$ compared to domestic commercial banks, the non-parametric Mann-Whitney and Kruskall-Wallis tests support the findings.

Table 6 Statistic Tests for the Efficiency Score of Commercial Banks 2008-2019

\begin{tabular}{|c|c|c|c|c|c|c|}
\hline \multicolumn{7}{|c|}{ Test Groups } \\
\hline \multirow{3}{*}{ Test Statistic } & \multirow{2}{*}{\multicolumn{2}{|c|}{$\begin{array}{l}\text { Parametric Test } \\
\text { T-test } \\
t(\text { Prb }>t)\end{array}$}} & \multicolumn{2}{|c|}{ Non-Parametric Test } & & \\
\hline & & & $\begin{array}{l}\text { Mann-Whitr } \\
z(\text { Prb }>z)\end{array}$ & test & \multicolumn{2}{|c|}{$\begin{array}{l}\text { Kruskall-Wallis test } \\
X^{2}\left(\operatorname{Prb}>X^{2}\right)\end{array}$} \\
\hline & Mean & $\mathrm{t}$ & Mean Rank & $z$ & Mean Rank & $\mathrm{X}^{2}$ \\
\hline \multicolumn{7}{|c|}{ Technical Efficiency } \\
\hline DCB & 0.902 & 1.353 & 113.83 & -0.687 & 113.83 & 0.472 \\
\hline FCB & 0.882 & & 107.92 & & 107.92 & \\
\hline \multicolumn{7}{|c|}{ Pure Technical Efficiency } \\
\hline DCB & 0.979 & $3.901 * * *$ & 124.96 & $-3.209 * * *$ & 124.96 & $10.297 * * *$ \\
\hline FCB & \multicolumn{3}{|c|}{ Scale Efficiency } & & 99.31 & \\
\hline DCB & 0.921 & -1.380 & 100.26 & $-2.155^{* *}$ & 100.26 & $4.474^{* *}$ \\
\hline FCB & 0.936 & & 118.43 & & 118.43 & \\
\hline
\end{tabular}

\subsection{The Determinants of Technical Efficiency}

Table 7 portrays a correlation matrix for explanatory variables. All coefficients of the variables are less than 0.8 , which indicates that there are no multicollinearity problems. BPLM and Hausman tests indicate the random-effects model is more suitable. Table 8 summarizes the result of panel regression under a random-effects model for the technical efficiency and its determinants for Malaysian commercial banks throughout 2008-2019.

Table 8 shows a positive association between bank size (LNTA) and technical efficiency that is statistically important at a $1 \%$ level, $5 \%$, and $10 \%$ levels (except model $5,7,10$ ). The finding agrees with Sufian et al., (2016). This result indicates the large bank is more efficient than small banks. However, taking macroeconomic factors into account, bank size (LNTA) and technical efficiency are inversely correlated and not significantly related.

The results show a negative relationship between technical efficiency and credit risk (LNNPLs) that is statistically significant at $1 \%, 5 \%$, and $10 \%$ levels (except models $5,7,9,10$ ). This finding is consistent with Karim, Chan, and Hassan (2010); Berger, (2009); Abel, (2018); Partovi and Matousek (2019). This result tests the possibility that banks with more non-performing loans may exhibit lower levels of efficiency. 
The empirical findings indicate that capitalization (LNETA) improves the technical efficiency of commercial banks at $1 \%, 5 \%$, and $10 \%$ levels (except model 10). It means that a bank with a higher capitalization tends to be more technically efficient. Previous research by Ismail, Majid, and Rahim (2013) and Ahmad and Noor (2011) supports the conclusion that the capitalization level has a positive effect on bank performance.

The sign of the bank diversification coefficient (LNNIIGR) for commercial banks (except for model 7) has shown a negative sign throughout (significantly at $1 \%, 5 \%$, and $10 \%$ levels), indicating that banks with a high proportion of interest-free income in gross revenue would be less efficient despite diversifying their income. This finding contradicts the finding of Tan \& Anchor, (2017), which found a positive correlation with technical efficiency. The findings exemplify that a higher percentage of noninterest income will weaken the bank's lending business and further reduce interest income, thus reducing the demand for banking business, which is detrimental to the bank.

During the research period, we also discover that bank market power (LNBDTD) has consistently exhibited a positive sign (significantly at $1 \%$ level) for commercial banks. This result reveals that banks with significant market power have a beneficial effect on banking services. This finding is contradicting the finding of Kamarudin et al., (2019) found a negative relationship with bank efficiency. Greater market power strengthens banking services more efficiently than those with less power.

In terms of the effect of liquidity (LNLOANSTA) on technical efficiency, Table 9 shows that liquidity at a $1 \%$ significance level is positive and statistically important. This agrees with Sufian (2009), who found that banks with more liquidity are more effective. Efficient banks can manage their operations efficiently and therefore potentially have lower production costs, which allows them to offer more reasonable loan terms and ultimately gain a larger market share than inefficient banks.

In terms of financial liberalization policy, the coefficient of the economic situation is negative and statistically significant at $5 \%$ (except models $2,5,10,11$ ). The results show that negative economic conditions can affect bank efficiency. This may be due to volatile economic growth, which reduces demand for banks' financial services and increases loan defaults, lowering output (Kamrudin et al., 2016b).

Finally, the findings show that inflation (LNINFL) has a significant negative relationship with bank efficiency and that this relationship is significant at $1 \%$ and $5 \%$ levels (except model 11 ). This means that a high inflation rate leads to a decrease in the technical efficiency of banks which is in line with the study by Tan and Anchor (2019). High inflation rates reduce the demand for banking services while increasing banks' regulatory and administrative costs for loans will reduce their technical efficiency. Due to the fact that borrowers believe lower inflation will lead to lower interest rates on future loans and thus a reduction in business demand for loans.

\subsection{Robustness Checks: Controlling for Financial Liberalization Policy}

To find out the reaction of commercial banks on the financial liberalization policy, we employ 8 interaction variables that include Interaction variables of all bank-specific and macroeconomic factors with FLP namely LNTA*FLP, LNNPLs*FLP, LNETA*FLP, LNNIIGR*FLP, LNBDTD*FLP, LNLOANSTA*FLP, LNGDP*FLP, LNINFL*FLP are introduced in Model 4-11.

According to the result (ref tab.8), the coefficient signs of LNTA*FLP in model 4 reflecting there is a positive relationship between bank size and technical efficiency of commercial banks and statistical significance at $1 \%$, which suggests that the larger banks will have higher technical efficiency. Furthermore, the capitalization (LNETA*FLP) in model 6 is a positive impact on liberalization and is significant at a $1 \%$ level. A higher capitalization of the bank tends to lead to higher technical efficiency. Similarly, the positive sign of the bank market power coefficient (LNBDTD*FLP) suggests that strong market power tends to increase bank efficiency. In addition, the empirical results in model 9 indicate that the effects of liquidity (LNLOANSTA*FLP) on liberalization are positive, which implies that higher liquidity improves bank efficiency.

On the other hand, if the effects of liberalization are controlled, then in model 5 it can be observed 
that the impact of credit risk (LNNPLs*FLP) becomes insignificant, suggesting that credit risk loses its explanatory power. It is worth noting that bank diversification (LNNIIGR*FLP) turns out to be positive in model 7. The results seem to suggest that the higher ratio of non-interest income to gross revenue tends to have higher bank efficiency during the liberalization period. Similarly, the coefficient sign of economic condition (LNGDP*FLP) in model 10 convert to a positive sign at a $1 \%$ significance level indicates that a good economic condition tends to increase the bank efficiency. The LNINFL*FLP in model 11 representing inflation shows a positive correlation with technical efficiency at the $1 \%$ level of significance. Based on the regression results, we believe that government intervention stimulates bank efficiency to a certain extent.

\section{Conclusion}

In this study, the technical efficiency, pure technical efficiency and scale efficiency of commercial banks in Malaysia were calculated, as well as the impact of liberalization on determinants of bank efficiency. To attain the objectives of this research, we used 8 domestic and 11 foreign commercial banks with coverage from 2008 to 2019 by using DEA and multivariate panel regression.

After the implementation of liberalization measures, the efficiency of both domestic and foreign banks has increased to some extent. The increasing number of foreign banks implies that market competition can force banks to become more efficient, as the "Quiet Life Hypothesis". The parametric T-test and non-parametric Mann-Whitney and Kruskall-Wallis tests indicate that domestic commercial banks' pure technical efficiency is higher than foreign banks and are significant at a $1 \%$ level. On the contrary, non-parametric Mann-Whitney and Kruskall-Wallis tests suggest foreign commercial banks are more efficient in scale than their domestic partners and are statistically significant at $1 \%$.

The second objective of the current study is to identify the effects of liberalization on determinants of bank efficiency. By using multivariate panel regression models to measure bank-specific, macroeconomic, and interaction variables. Based on the regression results for all commercial banks, bank efficiency is positively impacted by bank size, capitalization, bank market power, and liquidity. Meanwhile, bank diversification, credit risk, and inflation exhibit a negative relationship with the technical efficiency of commercial banks. When we control for the liberalization policy effects, bank diversification, the economic condition, and inflation will have a positive effect on bank efficiency, while credit risk loses its explanatory power.

The findings of this study are expected to make a significant contribution to the existing literature on the commercial banking industry in Malaysia. In addition, this study also provides a further reference for the specific management of banks as well as policy makers to provide an objective basis for assessing the impact of the implementation of the 2009 liberalization policy on the efficiency of banks and the management performance of bank managers. Finally, the sustainable development of the Malaysian banking sector is achieved in the rational optimization of policy and bank management in response to the findings of the study.

This study investigates the bank efficiency of commercial banks in Malaysia and provides stakeholders with a more intuitive picture of bank performance. First, commercial bank managers should improve liquidity in order to maximize output and thus improve technical efficiency. Second, managers should enhance credit risk management and improve technical efficiency by reducing unnecessary costs by lowering non-performing loans. Third, managers need to keep the proportion of non-interest income within a certain range and improve bank efficiency by increasing the revenue capacity of its core business - lending. Finally, the government should keep inflation within a reasonable limit to ensure healthy and stable economic growth.

This paper also has some shortcomings as it only measures the determinants of technical efficiency of commercial banks. The revenue, cost, and profitability efficiency could be examined if the input prices are available. Future research could further investigate the revenue efficiency, cost, and profitability efficiency of commercial banks in Malaysia. Second, the improved statistical method Bootstrap DEA can be used to obtain more robust results. 
Table 7 Correlation Matrix for Determinants of Commercial Banks 2008-2019

\begin{tabular}{|c|c|c|c|c|c|c|c|c|c|}
\hline & LNTA & LNNPLs & LNETA & LNNIIGR & LNBDTD & LNLOANTSA & LNGDP & LNINFL & FLP \\
\hline LNTA & 1 & & & & & & & & \\
\hline LNNPLS & $0.360 * * *$ & 1 & & & & & & & \\
\hline LNETA & $-0.680 * * *$ & $-0.231 * * *$ & 1 & & & & & & \\
\hline LNNIIGR & $0.315^{* * *}$ & $-0.401 * * *$ & $-0.393 * * *$ & 1 & & & & & \\
\hline LNBDTD & $-0.392 * * *$ & $-0.138 * *$ & $0.264 * * *$ & $-0.251 * * *$ & 1 & & & & \\
\hline LNLOANSTA & $0.404 * * *$ & $0.451 * * *$ & $-0.215 * * *$ & $-0.327 * * *$ & $-0.118^{*}$ & 1 & & & \\
\hline LNGDP & 0.0550 & -0.0880 & $0.387 * * *$ & 0.0160 & 0.0850 & 0.0400 & 1 & & \\
\hline LNINFL & -0.00400 & 0.0400 & $-0.145^{* *}$ & -0.0250 & 0.00600 & -0.00600 & $-0.159 * *$ & 1 & \\
\hline FLP & 0.00700 & -0.0910 & $0.245^{* * *}$ & -0.0150 & 0.0970 & 0.0290 & $0.649 * * *$ & 0.0500 & 1 \\
\hline
\end{tabular}

Table 8 Multivariate Panel Regression under Random Effects Model

\begin{tabular}{|c|c|c|c|c|c|c|c|c|c|c|c|}
\hline & $\begin{array}{l}\text { Model } 1 \\
\text { REM } \\
\end{array}$ & $\begin{array}{l}\text { Model } 2 \\
\text { REM }\end{array}$ & $\begin{array}{l}\text { Model } 3 \\
\text { REM }\end{array}$ & $\begin{array}{l}\text { Model } 4 \\
\text { REM }\end{array}$ & $\begin{array}{l}\text { Model } 5 \\
\text { REM }\end{array}$ & $\begin{array}{l}\text { Model } 6 \\
\text { REM }\end{array}$ & $\begin{array}{l}\text { Model } 7 \\
\text { REM }\end{array}$ & $\begin{array}{l}\text { Model } 8 \\
\text { REM }\end{array}$ & $\begin{array}{l}\text { Model } 9 \\
\text { REM }\end{array}$ & $\begin{array}{l}\text { Model } 10 \\
\text { REM }\end{array}$ & $\begin{array}{l}\text { Model } 11 \\
\text { REM }\end{array}$ \\
\hline Constant & $\begin{array}{l}-0.678 * * * \\
(0.162)\end{array}$ & $\begin{array}{l}-0.729 \\
(0.526)\end{array}$ & $\begin{array}{l}0.890 \\
(0.567)\end{array}$ & $\begin{array}{l}0.778 \\
(0.535) \\
\end{array}$ & $\begin{array}{l}-1.028^{* *} \\
(0.524) \\
\end{array}$ & $\begin{array}{l}1.039 * \\
(0.538)\end{array}$ & $\begin{array}{l}0.787 \\
(0.573) \\
\end{array}$ & $\begin{array}{l}0.549 \\
(0.533)\end{array}$ & $\begin{array}{l}0.924 * * \\
(0.413)\end{array}$ & $\begin{array}{l}-0.314^{*} \\
(0.165) \\
\end{array}$ & $\begin{array}{l}-0.858 \\
(0.535) \\
\end{array}$ \\
\hline \multicolumn{12}{|c|}{ Bank Specific Variables } \\
\hline LNTA & $\begin{array}{l}0.022 * * * \\
(0.008)\end{array}$ & $\begin{array}{l}0.019 * * \\
(0.009)\end{array}$ & $\begin{array}{l}0.018 * * \\
(0.009)\end{array}$ & & $\begin{array}{l}0.016 * \\
(0.010)\end{array}$ & $\begin{array}{l}0.013^{*} \\
(0.007)\end{array}$ & $\begin{array}{l}0.011 \\
(0.009)\end{array}$ & $\begin{array}{l}0.022 * * \\
(0.011)\end{array}$ & $\begin{array}{l}0.026 * * * \\
(0.008)\end{array}$ & $\begin{array}{l}0.002 \\
(0.008)\end{array}$ & $\begin{array}{l}0.020 * * \\
(0.009)\end{array}$ \\
\hline LNNPLs & $\begin{array}{l}-0.019 * * * \\
(0.007)\end{array}$ & $\begin{array}{l}-0.019 * * * \\
(0.007)\end{array}$ & $\begin{array}{l}-0.014 * \\
(0.008)\end{array}$ & $\begin{array}{l}-0.013 * \\
(0.007)\end{array}$ & & $\begin{array}{l}-0.012 * \\
(0.007)\end{array}$ & $\begin{array}{l}-0.007 \\
(0.009)\end{array}$ & $\begin{array}{l}-0.015^{* *} \\
(0.007)\end{array}$ & $\begin{array}{l}-0.012 \\
(0.008)\end{array}$ & $\begin{array}{l}-0.009 \\
(0.008)\end{array}$ & $\begin{array}{l}-0.015^{* *} \\
(0.007)\end{array}$ \\
\hline LNETA & $\begin{array}{l}0.091 * * * \\
(0.026)\end{array}$ & $\begin{array}{l}0.077 * * \\
(0.038)\end{array}$ & $\begin{array}{l}0.085 * * \\
(0.040)\end{array}$ & $\begin{array}{l}0.065 * * \\
(0.032)\end{array}$ & $\begin{array}{l}0.072 * \\
(0.038)\end{array}$ & & $\begin{array}{l}0.101 * * \\
(0.040)\end{array}$ & $\begin{array}{l}0.084 * \\
(0.047)\end{array}$ & $\begin{array}{l}0.084 * * \\
(0.041)\end{array}$ & $\begin{array}{l}0.015 \\
(0.021)\end{array}$ & $\begin{array}{l}0.088 * * \\
(0.039)\end{array}$ \\
\hline LNNIIGR & $\begin{array}{l}-0.060 * * \\
(0.030)\end{array}$ & $\begin{array}{l}-0.063 * * \\
(0.031)\end{array}$ & $\begin{array}{l}-0.052^{*} \\
(0.030)\end{array}$ & $\begin{array}{l}-0.050 * \\
(0.029)\end{array}$ & $\begin{array}{l}-0.051^{*} \\
(0.031)\end{array}$ & $\begin{array}{l}-0.053^{*} \\
(0.032)\end{array}$ & & $\begin{array}{l}-0.055^{*} \\
(0.030)\end{array}$ & $\begin{array}{l}-0.074 * * * \\
(0.028)\end{array}$ & $\begin{array}{l}-0.063^{*} \\
(0.033)\end{array}$ & $\begin{array}{l}-0.052^{*} \\
(0.032)\end{array}$ \\
\hline LNBDTD & $\begin{array}{l}0.035^{* * *} \\
(0.012)\end{array}$ & $\begin{array}{l}0.034^{* * *} \\
(0.011)\end{array}$ & $\begin{array}{l}0.034 * * * \\
(0.013)\end{array}$ & $\begin{array}{l}0.033^{* *} \\
(0.013)\end{array}$ & $\begin{array}{l}0.032 * * * \\
(0.011)\end{array}$ & $\begin{array}{l}0.030 * * \\
(0.012)\end{array}$ & $\begin{array}{l}0.040 * * * \\
(0.013)\end{array}$ & & $\begin{array}{l}0.034^{* *} \\
(0.013)\end{array}$ & $\begin{array}{l}0.026 * * \\
(0.011)\end{array}$ & $\begin{array}{l}0.034 * * * \\
(0.012)\end{array}$ \\
\hline LNLOANSTA & $\begin{array}{l}0.063^{* * *} \\
(0.024)\end{array}$ & $\begin{array}{l}0.063 * * * \\
(0.024)\end{array}$ & $\begin{array}{l}0.064 * * * \\
(0.020)\end{array}$ & $\begin{array}{l}0.067 * * * \\
(0.019)\end{array}$ & $\begin{array}{l}0.060 * * * \\
(0.022)\end{array}$ & $\begin{array}{l}0.062 * * * \\
(0.020)\end{array}$ & $\begin{array}{l}0.077^{* * *} \\
(0.021)\end{array}$ & $\begin{array}{l}0.060 * * * \\
(0.022)\end{array}$ & & $\begin{array}{l}0.058 * * * \\
(0.022)\end{array}$ & $\begin{array}{l}0.062 * * * \\
(0.023)\end{array}$ \\
\hline Macroeconc & riables & & & & & & & & & & \\
\hline LNGDP & & $\begin{array}{l}0.010 \\
(0.044)\end{array}$ & $\begin{array}{l}-0.118^{* *} \\
(0.048)\end{array}$ & $\begin{array}{l}-0.093 * * \\
(0.043)\end{array}$ & $\begin{array}{l}0.033 \\
(0.044)\end{array}$ & $\begin{array}{l}-0.111 * * * \\
(0.039)\end{array}$ & $\begin{array}{l}-0.126^{* * *} \\
(0.048)\end{array}$ & $\begin{array}{l}-0.087^{*} \\
(0.047)\end{array}$ & $\begin{array}{l}-0.102^{* *} \\
(0.041)\end{array}$ & & $\begin{array}{l}0.013 \\
(0.043)\end{array}$ \\
\hline
\end{tabular}




\begin{tabular}{|c|c|c|c|c|c|c|c|c|c|c|c|}
\hline \multicolumn{2}{|l|}{ LNINFL } & $\begin{array}{l}-0.010^{*} \\
(0.005)\end{array}$ & $\begin{array}{l}-0.020 * * * \\
(0.006)\end{array}$ & $\begin{array}{l}-0.020^{* * *} \\
(0.006)\end{array}$ & $\begin{array}{l}-0.009^{*} \\
(0.005)\end{array}$ & $\begin{array}{l}-0.022^{* * *} \\
(0.007)\end{array}$ & $\begin{array}{l}-0.018^{* * *} \\
(0.006)\end{array}$ & $\begin{array}{l}-0.017^{* * *} \\
(0.006)\end{array}$ & $\begin{array}{l}-0.019 * * * \\
(0.006)\end{array}$ & $\begin{array}{l}-0.017^{* * *} \\
(0.006)\end{array}$ & \\
\hline \multicolumn{2}{|l|}{ FLP } & & $\begin{array}{l}0.128 * * * \\
(0.043)\end{array}$ & & & & & & & & \\
\hline \multicolumn{12}{|c|}{ Interaction Variables } \\
\hline LNTA*FLP & & & & $\begin{array}{l}0.011^{* * *} \\
(0.004)\end{array}$ & & & & & & & \\
\hline LNNPLs*FLP & & & & & $\begin{array}{l}-0.012 \\
(0.008)\end{array}$ & & & & & & \\
\hline LNETA*FLP & & & & & & $\begin{array}{l}0.067^{* * *} \\
(0.020)\end{array}$ & & & & & \\
\hline LNNIIGR*FLP & & & & & & & $\begin{array}{l}0.034 * * * \\
(0.011)\end{array}$ & & & & \\
\hline LNBDTD*FLP & & & & & & & & $\begin{array}{l}0.044 * * * \\
(0.011)\end{array}$ & & & \\
\hline LNLOANSTA*FLP & & & & & & & & & $\begin{array}{l}0.031^{* * * *} \\
(0.009)\end{array}$ & & \\
\hline LNGDP*FLP & & & & & & & & & & $\begin{array}{l}0.007^{* * *} \\
(0.003)\end{array}$ & \\
\hline LNINFL*FLP & & & & & & & & & & & $\begin{array}{l}0.028^{* *} \\
(0.012)\end{array}$ \\
\hline $\mathrm{N}$ & 213 & 213 & 213 & 213 & 213 & 213 & 213 & 213 & 213 & 213 & 213 \\
\hline R2 & 0.189 & 0.193 & 0.258 & 0.244 & 0.183 & 0.261 & 0.223 & 0.237 & 0.236 & 0.237 & 0.203 \\
\hline Wald chi2 & 152.316 & 155.777 & 160.897 & 143.820 & 154.962 & 205.399 & 141.775 & 242.295 & 113.817 & 197.435 & 144.910 \\
\hline BP \& LM X2 & $10.56 * * *$ & $10.44 * * *$ & $14.81 * * *$ & $14.55^{* * *}$ & $10.39 * * *$ & $15.82 * * *$ & $29.20 * * *$ & $14.83 * * *$ & $11.03 * * *$ & $14.23 * * *$ & $11.36 * * *$ \\
\hline Hausman X2 & 1.28 & 2.67 & 4.61 & 3.97 & 3.26 & 5.46 & 6.89 & 4.37 & 5.90 & 8.81 & 3.08 \\
\hline$p$-value & 0.973 & 0.953 & 0.867 & 0.860 & 0.917 & 0.707 & 0.548 & 0.822 & 0.658 & 0.358 & 0.929 \\
\hline VIF & $1.19-2.56$ & $1.05-3.25$ & $1.09-3.25$ & $1.08-2.51$ & $1.05-3.28$ & $1.06-2.50$ & $1.08-3.09$ & $1.07-3.20$ & $1.08-3.22$ & $1.06-2.80$ & $1.02-3.22$ \\
\hline
\end{tabular}




\section{References}

1. Abel, S. (2018). Cost efficiency and non-performing loans: An application of the Granger causality test. Journal of Economic and Financial Sciences, 11(1), 1-8.

2. Ahmad, N.H. and Noor, M.A.N.M. (2011), "The determinants efficiency and profitability of world Islamic banks", 2010 International Conference on E-business, Management and Economics IPEDR Vol.3 (2011), IACSIT Press, Hong Kong, pp. 228-233.

3. Ang, J. B., \& McKibbin, W. J. (2007). Financial liberalization, financial sector development and growth: Evidence from Malaysia. Journal of development economics, 84(1), 215-233.

4. Asteriou, D., \& Hall, S.G. (2007), Applied Econometrics, revised edition, New York: Palgrave Macmillan.

5. Azad, M. A. K., Munisamy, S., Masum, A. K. M., Saona, P., \& Wanke, P. (2017). Bank efficiency in Malaysia: a use of malmquist meta-frontier analysis. Eurasian Business Review, 7(2), 287-311.

6. Bader, M. K. I., Mohamad, S., Ariff, M., and Hassan, T. (2008). "Cost, revenue and profit efficiency of Islamic versus conventional banks: International evidence using Data Envelopment Analysis". Islamic Economic Studies, 15(2), 23-76.

7. Bank Negara Malaysia (1999a). Consolidation and Rationalization of the Domestic Banking Institutions. Retrieved 10 May 2021, from https://www.bnm.gov.my/-/consolidation-andrationalisation-of-the-domestic-banking-institutions.

8. Bank Negara Malaysia (1999b). Tax Incentives for Consolidation of Domestic Banking institutions. Retrieved 10 May 2021, from https://www.bnm.gov.my/-/tax-incentives-for-consolidation-ofdomestic-banking-institutions.

9. Bank Negara Malaysia (2009). Financial Sector Blueprint 2011-2020. Retrieved 10 May 2021, from https://www.bnm.gov.my/-/financial-sector-blueprint-2011-2020.

10.Bank Negara Malaysia (2011). Liberalization of the Financial Sector. Retrieved 10 May 2021, from https://www.bnm.gov.my/-/liberalisation-of-the-financial-sector.

11.Bank Negara Malaysia (2019). Financial Stability and Payment Systems Report 2018. Retrieved 10 May 2021, from https://www.bnm.gov.my/-/fspr2018.

12.Banker, R. D., Charnes, A., \& Cooper, W. W. (1984). Some models for estimating technical and scale inefficiencies in data envelopment analysis. Management science, 30(9), 1078-1092.

13.Banker, R.D. and Natarajan, R. (2005), "Productivity change, technical progress, and relative efficiency change in the public accounting industry", Management Science, Vol. 51 No. 2, pp. 291304.

14.Banker, R.D., Chang, H. and Lee, S.Y. (2010), "Differential impact of Korean banking system reforms on bank productivity", Journal of Banking and Finance, Vol. 34 No. 7, pp. 1450-1460.

15.Berger, A. N., Hasan, I., \& Zhou, M. (2009). Bank ownership and efficiency in China: What will happen in the world's largest nation?. Journal of Banking \& Finance, 33(1), 113-130.

16.Charnes, A., Cooper, W. W., \& Rhodes, E. (1978). Measuring the efficiency of decision making units. European journal of operational research, 2(6), 429-444.

17.Coelli,T.,Prasada-Rao, D.S., \& Battese, G.E. (1998). An introduction to efficiency and productivity analysis. Boston: Kluwer Academic Publishers.

18.Cooper, W. W., Seiford, L. M., \& Zhu, J. (Eds.). (2011). Handbook on data envelopment analysis.

19.Cosar, E. E. (2012). Price and income elasticities of Turkish export demand: a panel data application. Central Bank Review, 2(2), 19-53.

20.Haque, M. I., Tausif, M. R., \& Anis, A. (2020). Continued discussion on conventional versus Islamic banks: combining financial ratios and efficiency. Banks and Bank Systems, 15(1), 132.

21.Hicks, J. R. (1935). Annual survey of economic theory: the theory of monopoly. Econometrica: Journal of the Econometric Society, 1-20.

22.Gujarati, D. N., \& Porter, D. (2009). Basic Econometrics Mc Graw-Hill International Edition.

23. Hoechle, D. (2007). Robust standard errors for panel regressions with cross-sectional dependence. The stata journal, 7(3), 281-312. 
24.Hou, X., Wang, Q., \& Zhang, Q. (2014). Market structure, risk taking, and the efficiency of Chinese commercial banks. Emerging Markets Review, 20, 75-88.

25.Ismail, F., Majid, M.S.A. and Rahim R.A. (2013), "Efficiency of Islamic and conventional banks in Malaysia", Journal of Financial Reporting and Accounting, Vol. 11 No. 1, pp. 92-107.

26.Kamarudin, F., Sufian, F., \& Nassir, A. M. (2016a). Does country governance foster revenue efficiency of Islamic and conventional banks in GCC countries? EuroMed Journal of Business.

27.Kamarudin, F., Sufian, F., \& Nassir, A. M. (2016b). Global financial crisis, ownership and bank profit efficiency in the Bangladesh's state owned and private commercial banks. Contaduría y Administración, 61(4), 705-745.

28. Kamarudin, F., Sufian, F., Loong, F. W., \& Anwar, N. A. M. (2017). Assessing the domestic and foreign Islamic banks efficiency: Insights from selected Southeast Asian countries. Future Business Journal, 3(1), 33-46.

29.Kamarudin, F., Sufian, F., Nassir, A. M., Anwar, N. A. M., \& Hussain, H. I. (2019). Bank efficiency in Malaysia a DEA approach. Journal of Central Banking Theory and Practice, 8(1), 133-162.

30.Kamarudin, F., \& Yahya, M. H. (2013). Cost, Revenue and Profit Efficiency in Islamic vs Conventional Banks: Empirical Evidence using Data Envelopment Analysis (DEA). Pertanika Journal Social Science and Humanity, 21(5), 1-18.

31.Kasim, M.M., Ramli, R., Baten, M.A., Jamil, J.M., Taleb, M. (2019). "Efficiency of Banks in Malaysia: a Super Efficiency Approach." Engineering Economics, 30(4), 442-450.

32.Loong, F., Kamarudin, F., Sufian, F., \& Naseem, N. A. M. (2017). Estimating Efficiency in Domestic and Foreign Islamic Banking and Its Determinants among Three Neighboring Countries-Malaysia, Indonesia and Brunei. International Journal of Economics \& Management, 11(1).

33.Ng, K.H., Wong, S.C., Yap, P.K., Khezrimotlagh, D. (2014). "A Survey on Malaysia's Banks Efficiency: Using Data Envelopment Analysis." Scholars Journal of Economics: Business and Management. 1(11):586-592.

34.Njie, M. (2007). Impact of financial liberalization on the productive efficiency of the banking industry in Malaysia. Banker's Journal Malaysia, 131(1), 49-67.

35.Ong, T.S., Lim, Y.T., Teh, B.H. (2011). "A Comparison on Efficiency of Domestic and Foreign Banks in Malaysia: A DEA Approach." Business Management Dynamics. Vol.1, No.4, pp.33-49.

36.Pancurova, D., \& Lyocsa, S. (2013). Determinants of commercial banks' efficiency: evidence from 11 CEE Countries. Finance a Uver, 63(2), 152.

37.Partovi, E., \& Matousek, R. (2019). Bank efficiency and non-performing loans: Evidence from Turkey. Research in international Business and Finance, 48, 287-309.

38. Rahim, R. A. (2017). Efficiency and competition in the Malaysian banking market: Foreign versus domestic banks. Gadjah Mada International Journal of Business, 19(2), 193-221. https://doi.org/10.22146/gamaijb.6106.

39.Saha, A., Ahmad, N. H., \& Dash, U. (2015). Drivers of technical efficiency in Malaysian banking: a new empirical insight. Asian-Pacific Economic Literature, 29(1), 161-173.

40.Sufian, F. (2009). "Determinants of bank efficiency during unstable macroeconomic environment: empirical evidence from Malaysia," Research in International Business and Finance, vol. 23, no. 1, pp. 54-77.

41.Sufian, F., \& Kamarudin, F. (2015). Determinants of revenue efficiency of Islamic banks. International Journal of Islamic and Middle Eastern Finance and Management.

42.Sufian, F., Kamarudin, F., Nassir, A. M., (2016). Determinants of efficiency in the Malaysian banking sector: Does bank origins matter?. Intellectual Economics, 10(1), 38-54.

43.Tan, Y., \& Anchor, J. (2017). The impacts of risk-taking behaviour and competition on technical efficiency: evidence from the Chinese banking industry. Research in International Business and Finance, 41, 90-104.

44.Tuo, M.X. (2016). An Empirical Analysis of Chinese Commercial Banks' Efficiency and Influencing Factors. American Journal of Industrial and Business Management, 6, 455-466.

http://dx.doi.org/10.4236/ajibm.2016.64042. 